\title{
Network structure and open innovation: the role of trust in product development
}

\author{
Aluisius Hery Pratono \\ Faculty of Business and Economics, \\ Universitas Surabaya, \\ Raya Kalirungkut Surabaya 60293, Indonesia \\ Email: hery_pra@staff.ubaya.ac.id
}

\begin{abstract}
The challenge of implementation of open innovation to new product development does not only spring from the margin of managerial action but also from network structure. However, there is a complex relationship between network structure and product development that allows firms to achieve performance. Along with the survey on SMEs in the Indonesian context, this study demonstrates empirically that firms with extended expansion of network structures will not achieve per performance, unless they can build trust and product development capability upon the networks. The result confirms that combination between social capital theory and dynamic capability enhances the explanation on firm performance.
\end{abstract}

Keywords: SMEs; network structure; product development; firm performance.

Reference to this paper should be made as follows: Pratono, A.H. (2018)

'Network structure and open innovation: the role of trust in product development', Int. J. Business Innovation and Research, Vol. 15, No. 1, pp.44-61.

Biographical notes: Aluisius Hery Pratono is a Lecturer at the Faculty of Business and Economics, Universitas Surabaya, Indonesia. He also serves as the Head of Centre for Business and Industrial Studies. He received his $\mathrm{PhD}$ from the Universiti Utara Malaysia, MA from the Asian Institute of Management in the Philippines, and BA in Economics from the Gadjah Mada University, Indonesia.

\section{Introduction}

Open innovation paradigm has brought essential issue in product development process on how firms achieve their sustainable competitiveness with open resources, more participatory, more distributed, and more decentralised approach to innovation (Chesbrough, 2003). This approach requires organisational capability to exhibit network effect on their offering products, which implies on firm performance (Afuah, 2013). Establishing vital commercial networks is essential for profitable firms to allow them to acquire and revamp valuable resources (Braguinsky and Hounshell, 2016).

On the other hand, some other studies argue that firms with greater social networks may suffer from poor performance, especially when there is an exploitation of relationship (Duffy et al., 2012). Another reason comes from the limited capability of 
firms to gain advantage from overwhelmed network structures (Terpend and Ashenbaum, 2012). The capability of firms to enhance their product development through alliance strategy is vary greatly, especially when they deal with overloaded information (Schilke, 2014).

The complex relationship between network structure and firm performance is challenging area for further inquiry that brings intersection between economics and sociology, which is becoming more and more important to strategy theory development (Afuah, 2013). Hence, this study tries to fill the research gap through introducing trust as mediating variable in order to understand the complex relationship between network structure and firm performance.

To investigate the outcomes of network structure and trust on firm performance in relationship with product development, this study proposes a structural equation model. The hypothesis development was derived from literature review and followed by cross-sectional survey, which is equated with a list of questionnaires. Data are derived from the random survey responses of $380 \mathrm{SMEs}$ in Indonesia. The information is required to answer the research questions quantifies relationship among observed variables, including firm performance, social-network structure, trust, and product development.

\section{Theoretical framework}

\subsection{Social capital theory}

This study gains support from social capital theory. Social capital refers to social relations among community members, which represent market exchange under hierarchical authority (Kwon and Adler, 2014). This resource is associated with "a kind, helpful, or friendly feeling or attitude", according to Merriam-Webster Dictionary. The main idea of social capital comes from social networks, which provides valuable resources to individual and society (Häuberer, 2010).

Social capital theory views that networks of relationships provide cooperation values among groups and individuals. In 1990s, the concept of social capital gains popularity, when World Bank focused on the concept of social capital to deal with declining public participation (Putnam, 2000).

Bourdieu and Coleman are the founders of social capital theory. They develop the concept of social capital systematically for the first time (Häuberer, 2010). Bourdieu develops the theory with economic term that social capital is associated with amount of relationships and partners' resource, which is then extend the concept of cultural capital (Tubadji, 2014). Coleman develops the concept in the context of social interdependency that allows individual success (Cvtanovic et al., 2015).

Both Bourdieu and Coleman confirm that social capital is a resource that embedded in relationship among actors (Häuberer, 2010). This means that dense network is associated with greater amount of social capital. Both also neglect the negative impact of social capital, a rises from exclusiveness that members of a dominant class maintain. Hence, Putnam (2000) develops the concept of social capital that concerns on societal equality.

Putnam (2000) highlights that high societal quality occurs when there is reciprocal social relationship and individuals generate relationship with trust, norm and network (Bjørnskov and Sønderskov, 2013). Trust also generates networks of community 
participation and civic society (Häuberer 2010). In this context, social capital is associated with public good with outcomes at the macro level. Then, Burt develops the concept of social capital with individual and a group.

In the context of individual, the concept of social capital highlights possession of financial to maximise the utility. Burt neglects social capital as a public good, including shared values and norms (Häuberer, 2010). The concept highlights the centrality of networks that brings a prestige to the author and existence of social structure (Marin et al., 2015).

\subsection{The dynamic capability}

The dynamic capability is the extension of the resource-based view (RBV) that highlights the organisation routines for interdependence actions (Schilke, 2014). The RBV classic works underlines the role of resources that firms require valuable resources to achieve greater performance (Penrose, 1959) that represents achievement level that business organisations meet their goal of profit maximisation (Spullberg, 2009).

Valuable resources cover all assets, capabilities, and knowledge that firms implement for their strategy (Barney, 1991). Specifically, capability refers to special type of resources that shows capability to deploy resources for greater productivity. Pricing capability refers to the ability of a firm to set price for their product to gain high revenue in the market (Murray et al., 2011). The emerging concept of pricing capability underpins the resource-based theory (Dutta et al., 2003). The theory explains how firms deploy their internal resource and capabilities in their pricing process to achieve their high level of competitive advantage (Liozu and Hinterhuber, 2013). Hence, business organisations that strive to be autonomous have more capability to access valuable resources under uncertainty business environment ( $\mathrm{Li}$ et al., 2013).

Autonomy is essential issue for entrepreneurial resources. Autonomy refers to freedom and flexibility that allow organisational members to develop entrepreneurial initiative (Lumpkin et al., 2009). In the context of organisation, autonomy refers to the relationship between units and sub-units on making decision and goal setting for them, which spring from autonomous and external motivation (Moran et al., 2012). Autonomy refers to freedom and flexibility that allow organisational members to develop entrepreneurial initiative (Lumpkin et al., 2009).

The theory of dynamic capability explains how firms value-creating strategies meet dynamic market to gain long-term competitive advantage (Eisenhardt and Martin, 2000). Firms with pricing capability to manage market power can increase the price of their products without any change of their demand. Firms that deploy their unique resources and increase their output may trigger their competitors to decrease their output (Costa et al., 2013).

In family businesses, both young owned-managers and non-family managers expect the top owned-managers provide more autonomy in management practices with open communication (Zellweger and Sieger, 2010). In the context of small businesses, autonomy is main personal reason to setup a self-employ business. For those who prefer to establish new venture than working for a company, personal satisfaction that springs from autonomy may often more important than business goals in small business (Hunter, 2012), which can lead toward greater job satisfaction (Langer, 2012).

The fact that a resource deployment does not always bring greater performance indicates that there is a risk of managerial failure (Huesch, 2013). This implies that the 
assumption of complementary resources is no always acceptable. Another reason may come from asymmetric information that has implication on underestimated resource (Huesch, 2013).

\subsection{Operational definition}

Network structure refers to a number of relationships, which indicates density of relationship (Afuah, 2013). Network structure is a dimension of social capital that explains firms' network of contacts, which involve the density of relationships or the ability to span different networks (Lockett et al., 2014).

Dense network is a highly connected web of actors (Alguezaui and Fillieri, 2010), which implies on a greater probability of forming connections with other actors (Hearnshaw and Wilson, 2013). On the other hand, spare network indicates a low connected web of actors and low probability of forming connection.

Open innovation is a product development process that involves open resources as well as participatory, more distributed, and decentralisation approach (Chesbrough, 2003) with inflow and outflow of knowledge to accelerate internal innovation (West et al., 2014).

Trust is a set of positive expectation of firms that allow them to reduce uncertainty (Para-Requena et al., 2012). Trust is associated with the relational dimension that underpins relationship (Lockett et al., 2014). In organisation context, this construct involves inter-personal trust and intra-organisational relationship to enhance the quality of social exchange (Kwon and Adler, 2014).

Product development refers to capability of firm to conduct innovation with new product and service offering to meet customers' needs (Murray et al., 2011). This construct provides greater level of differentiation to the firms, including new features, new technology, and new function, which are essential to gain business sustainability.

Firm performance refers to the level of achievement of firms towards their goals (Spullberg, 2009). The primary measures for SMEs refer to sales growth, employment growth, return on asset (ROA), return on investment (ROI), return on sales (ROS), or overall performance (Parkman et al., 2012).

SME stands for small medium enterprise. In Indonesia context, this refers to local firms with asset less than USD 760,000 and sales less than USD 3,815,000.

\subsection{Hypothesis development}

To explain the complex relationship between network structure and firm performance, this study proposes a framework, which involves five hypotheses.

Hypothesis 1 Social network structure has direct positive impact on firm performance.

Network structure is valuable asset to manage information, which implies on opportunities to firms to acquire benefit (Broadbridge, 2010). This construct demonstrates how firms deploy their resource to enhance the social networks that provides opportunities to go partnership with their stakeholders. The development of network structures is in line with development stages of firms, which encourages firms to manage their networks and the development of their social capital since early firm development stages (Jonsson and Lindbergh, 2013). 
Firm with more initiative to enhance the partnership is associated with more dynamic networks (Newman et al., 2006). Hence, the quality social networks are derived from the extent to which they are close-knit and emotionally connected (Clopton, 2011). Networks characterised by high intensity and low centralisation are indeed associated with greater firm performance (Grund, 2012). Greater network structure implies on greater social capital, which is essential resources for firm performance (Pratono and Mahmod 2014).

In investing social capital, firms may come to a dilemma whether they should focus on a dense network structures or sparse one (Alguezaui and Fillieri, 2010). Dense network structure provides more opportunity for developing reputation-building mechanism, norms reciprocity, and sharing identity among the member of a network. Forming and utilising of network resources as source of competitive advantage allows firms to achieve their performance (Suli et al., 2013).

On the other hand, firms with sparse network may benefit from free-flow information, knowledge and ideas (Alguezaui and Fillieri, 2010). The size of network may have no direct effect on performance, but rather plays a more significant role as a contextual influence on the way in which power can be effectively deployed in such relationships (Terpend and Ashenbaum, 2012). Firms with sparse-network structure focus on attractive partners because they are expected to translate the available information into valuable resources (Milanov and Shepherd, 2013).

Hypothesis 2a Trust provides mediating effect between social network structure and product development.

Innovation highly depends upon trust, which is considered as a complex and fragile resource (Dovey, 2009). Trust involves a set of positive expectation of firms and organisational members (Para-Requena et al., 2012). There are many of the constitutive features of innovation, including product development, which highly depend on high level of trust.

In the context of inter-organisational networks, trust plays pivotal element for firms through providing valuable resource to gain knowledge. High levels of trust show high quality of exchange relationship that implies on ability to access information, support and resources (Schaubroeck et al., 2013). In organisation context, social exchange relationship relies on inter-personal trust, which can reduce uncertainty in relationship and enhance the quality of social exchange (Kwon and Adler, 2014).

Trust can prevail independently due to wishful thinking; personal preference or personal opinion while mutual trust relies on investment from all of the partners. A trust-based relationship prevails when a member evaluates the other member as not risky or the risk level is under bearable limits (Oldroyd and Morris, 2012).

The developing social capital requires trust from stakeholders, which relies on unwritten social contract and instead of instrument. The amount of trust that exists within a group of people greatly affects the results they can achieve together. Trust allows social interactions to proceed on a simple and confident basis. Individuals who trust each other are more likely to share ideas and relevant information or to clarify problems. However, a continued existence of conflicts during product development is likely to strain the partnering process if not handled appropriately (Bstieler, 2006).

Inter-firm teamwork stimulates such process, which bring into a mutually reinforcing relationship among the group with trust formation. To some extent, trust reaches a level of critical mass, in which new ventures jump quickly through characteristic-based trust 
towards greater level of process-based trust (Gausdal and Hildrum, 2012). As cognitive and structural dimension of social capital indicates the importance of trust within groups, social capital enhances performance. Groups and teams within organisations offer dynamic relationship among group members (Clopton, 2011).

Hypothesis 2b Trust mediates the relationship between network structure and performance.

The positive impact of network structure on performance fervently rooted at social interaction between firms and their stakeholders (Alguezaui and Fillieri, 2010). The solid relationship between firms and their distributor indicates strong distribution capability, which largely depends on firms' ability to obtain information about channel member distribution. The valuable information to the firms can increase the benefits and decrease the cost and risk that distributors perceive.

Firms may achieve such perception through various approaches, such as undertaking investments to distributors or gaining distributor's trust (Frazier et al., 2009). A number of network structure show the participation of distribution which quires firm to be proactive in managing distributor's perspective perception (Gu et al., 2010). Another literature also support this argument that social capital becomes source of coordination system, which enables firms to gain comprehensive information to relevant decision making process (Jansen et al., 2011).

Hypothesis 3a Product development provides mediating effect between network structure and firm performance.

Network resources provides channel for product innovation and further more firm performance (Zheng et al., 2013). Firms with superior network structures may be better able to exploit their internal product development capabilities and thus enhance their performance (Zaheer and Bell, 2005). Firms with access to suppliers, competitors, and universities will have more opportunities to enhance their innovations process (Inauen and Shenker-Wicki, 2011). Higher openness towards customers and universities are more likely to increase product innovations, while the indirect effect indicates that partnership with customer and university increases firm performance.

According to the experiences of Chinese industry, imitation strategy traps firms in the market position as the suppliers are hesitant to transfer technology (Xie and White, 2006). Small firms with fewer network relationships tend to have incremental innovation, while firms with a radical innovation and diverse networks experience radical internationalisation (Chetty and Stangl, 2010). Hence, the benefit from knowledge in networks is lost if the network members cannot feel secure enough (Nätti et al., 2014).

Product development involves various interests of cultural agents, which bring significant impact of inbound product development on firm performance. The intensity of collaboration with different stakeholders (e.g., customers, suppliers, and cross-sector companies) determines the number of product and process innovations and on the percentage of sales of newly developed products (Inauen and Shenker-Wicki, 2011).

Hence, firms subsequently move to more collectivistic societies (Ma et al., 2014). In the context of SMEs, there is a perception of deficient access to resources in the existing cohesive and identity-based network structure. A perceived deficiency encourages the development of the structural dimension of social capital so that it becomes based on function rather than identity (Jonsson and Lindbergh, 2013). 
Hypothesis $3 \mathrm{~b}$ Product development provides mediating effect between trust and firm performance.

The development of trust is a longitudinal process that has important implication on firm performance (Fadol and Sandhu, 2013). Product development is part of the mechanism through which firms gain benefits from development of trust. This mechanism is more relevant when firms can adopt new technologies emerge in order to seize new opportunity for particular market segments (Eisenman, 2013). Firms with wide range of actors and arm's length relationship might be activated for innovation project (Rusanen et al., 2014).

Open innovative firms with product development lamented risk of failure rates to some extent. Trust is essential resource to deal with the risk of product development failure. Firms may leverage their existing successful brand name, especially at uncluttered market space (Pitta and Pitta, 2012). Another alternative is that firms may conceal the innovation for product development to prevent existing firms from adopting their innovation (Casadesus-Masanell and Zhu, 2013), which may implies on trust destruction.

High-trust organisations allow their people to be creative and innovative, while low-trust organisations concern on defending themselves (Ceserani, 2014). However, increasing trust does not always bring positive impact on innovation and product development. Low trust is not conducive to innovation, but too much trust may have negative impact on innovation (Bidault and Castello, 2010).

\section{Research method}

Given the research questions, this research uses quantitative method with small medium enterprises as unit analysis. The cross-sectional survey is carried out with a list of questionnaires through random sampling method. The information required to answer the research questions refers to quantify relationship among observed variables, including firm performance, social-network structure, trust, and product development.

This study employs a set of quantitative information that utilises a standardised set, which is expected to be consistently in comparison. The questions are designed to measure dichotomous responses with low/high questions for firm performance and disagree/agree for independent, mediating, and moderating variables on seven-point Likert scaling (1-7 ratings).

The measures of trust are adapted from the several existing studies. Specifically, the measures of trust are adapted from Lee and Sukoco (2007) and Laeequddin et al. (2010). The primary measures for SMEs refer to sales growth, employment growth, ROA, ROI, ROS, or overall performance (Parkman et al., 2012). The measures of structural networks were adapted from Para-Requena et al. (2012), while product development adapts from Trez and Luce (2012).

The unit analysis of this study is small businesses. Hence, the observed population relies on SME directory obtained from Indonesia Ministry of Trade and Industry. As the database shows that number of registered SMEs were more than 35,000, the study distributed 750 questionnaires to randomised selected owner-managers through postal 
services. To increase the respond rate, data collection followed up the distributed questionnaires through telephone interview. After the screening, this study used 380 data sample collected from the respondents.

To test the hypothesis, this study employs a structural equation model. The Smart PLS 2.0 is used to estimate the coefficients of each independent variable as well as to draw inferences about the true of all coefficients. The PLS approach relaxes the classical assumption (Hair et al., 2012). PLS model relies on the extension of mixture design, which may have mismatch some characteristics of PLS path modelling (Becker et al., 2013).

\section{Result}

General description of the sample shows that the observed firms have wide range of performance. Based on years of operation, most of the observed firms have experienced less than ten years. With 300 firms, they represent $76 \%$ of total observed SMEs. From these criteria, 107 firms consider that their performances are slightly higher with level 6 from 7 scales. The rest observed firms have experience between 11 and 20 years experience.

The correlation matrix shows the wide range of variance among the latent variables. The highest correlation occurs between network structure and trust with value of 0.79 , followed by the relationship between trust and firm performance at 0.67 . There is weakest relationship between network structure and product development at 0.41 . Discriminant validity suggests that the correlation should be lower that value of average variance extracted (AVE).

Table 1 Correlation matrix of latent variables

\begin{tabular}{lcccc}
\hline & $F P$ & $N S$ & $P D$ & Trust \\
\hline Firm performance (FP) & 1.000000 & & & \\
Network structure (NS) & 0.582956 & 1.000000 & & \\
Product development (PD) & 0.559068 & 0.410347 & 1.000000 & \\
Trust & 0.671250 & 0.799565 & 0.454917 & 1.0000 \\
\hline
\end{tabular}

Overall, the outer model analysis shows that measurement model is relevant. The value of standardised indicator loading should be greater 0.70 and loading of 0.4 is acceptable. Description of the outer model includes complete list of indicators at the appendix.

Table 2 shows various reliability measures. The values of AVE show that all variables have value greater than 0.5 , which indicates that all variables are considered to meet validity requirement (Byrne, 2010). This test shows that variances of the constructs are greater than the amount of variances due to measurement error, which implies that convergent validity of the observed variables is accepted. Table 2 also shows how the observed variables are internal consistency reliable. The measures come from values of $\mathrm{CR}$ and $\mathrm{CA}$, which are greater than 0.7 . 
Table 2 Quality criteria

\begin{tabular}{lcccccc}
\hline & $A V E$ & $C R$ & $R$-square & $C A$ & Communality & Redundancy \\
\hline FP & 0.582652 & 0.914289 & 0.534483 & 0.888432 & 0.582652 & 0.054962 \\
NS & 0.579422 & 0.792607 & & 0.708979 & 0.579422 & \\
PD & 0.628665 & 0.894102 & 0.212973 & 0.854058 & 0.628665 & 0.055229 \\
Trust & 0.655988 & 0.944685 & 0.639304 & 0.933655 & 0.655988 & 0.417109 \\
\hline
\end{tabular}

Description of the inner model shows the relationship among the latent variables (Figure 1). The primary criterion of inner model assessment is the $\mathrm{R}^{2}$ of firm performance as the dependent variable. The R-square of firm performance as the dependent variable is 0.534 , which indicates that the proportion of variation in firm performance as dependent variable is explained by the independent variables. Hence, the $\mathrm{R}^{2}$ of trust as a mediating variable is greater than $\mathrm{R}^{2}$ of product development and firm performance.

Figure 1 Path analysis

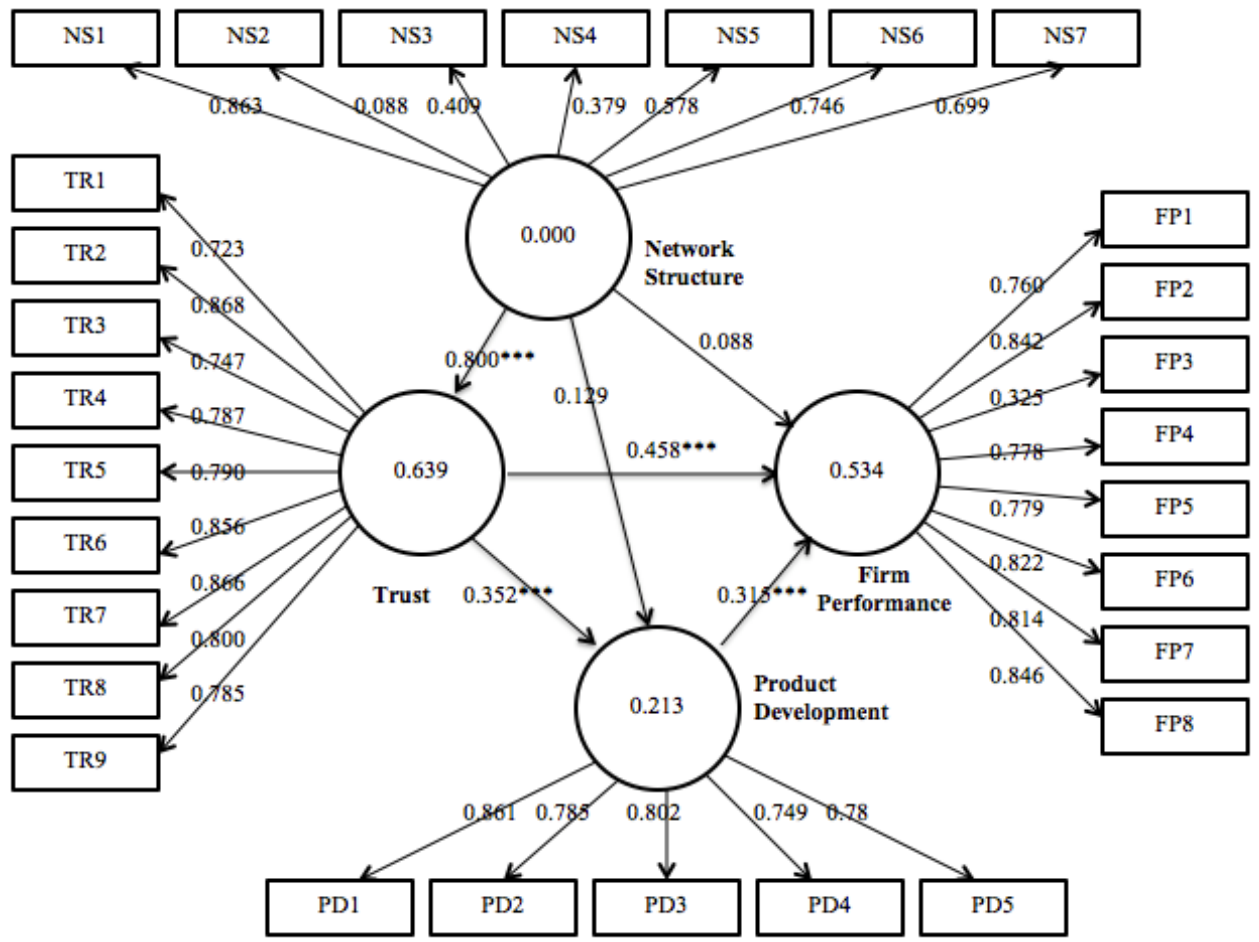

Note: $* * *$ Significant at alpha $5 \%$.

Table 3 shows standardised path coefficients, which represent the quality of inner model. The result indicates that $\mathrm{H} 1 \mathrm{a}$ is not accepted, which indicates that network structure has no direct significant effect on firm performance. This confirms the existing studies that size of network may have no direct effect on performance (Terpend and Ashenbaum, 2012). 
Table 3 Path coefficient

\begin{tabular}{lcccc}
\hline & $\begin{array}{c}\text { Original sample } \\
(O)\end{array}$ & $\begin{array}{c}\text { Sample mean } \\
(M)\end{array}$ & $\begin{array}{c}\text { Standard error } \\
(\text { STERR })\end{array}$ & $\begin{array}{c}\text { T statistics } \\
(\mid \text { OSTERR } \mid)\end{array}$ \\
\hline NS -> FP & 0.087542 & 0.085909 & 0.060099 & 1.456627 \\
NS -> PD & 0.129227 & 0.127142 & 0.082101 & 1.573999 \\
NS -> Trust & 0.799565 & 0.800376 & 0.021827 & $36.632327 * * *$ \\
PD -> FP & 0.314764 & 0.315669 & 0.046256 & $6.804793^{* * *}$ \\
Trust -> FP & 0.458063 & 0.459405 & 0.061029 & $7.505712^{* * *}$ \\
Trust -> PD & 0.351592 & 0.352672 & 0.071669 & $4.905765^{* * *}$ \\
\hline
\end{tabular}

Note: $* * *$ Significant at alpha $1 \%$

$\mathrm{H} 2 \mathrm{a}$ is accepted, which implies that trust mediates the relationship between network structure and product development. Trust provides full mediating effect on such relationship, as network structure has no direct significant impact on product development. This confirms the previous studies that trust is fragile resource and main determinant to open innovation (Dovey, 2009).

There are many of the constitutive features of innovation, including product development, which highly depend on high level of trust that involves a set of positive expectation of firms and organisational members (Para-Requena et al., 2012). High levels of trust show high quality of exchange relationship, which implies on ability to access information, support and resources (Schaubroeck et al., 2013).

$\mathrm{H} 2 \mathrm{~b}$ is accepted that indicates significant role of trust as a mediating variable. Product development becomes more relevant for firms with ability to network structure for longer time (Landwehr et al., 2013). In addition, the significant impact of social networks on firm performance indicates that business organisations with strong social networks enjoy greater performance as the feasibility of transactions in their networks, while the structural holes and ties within the networks determine the value that firms provide to customers (Afuah, 2013).

$\mathrm{H} 3 \mathrm{a}$ is not accepted that there is no mediating effect of product development on the relationship between network structure and firm performance. There is a complex evident of the contribution of networks on open innovation on account of the nature of business organisations (Clifton et al., 2010).

$\mathrm{H} 3 \mathrm{~b}$ is accepted that product development has significant effect as mediating variable that explains the relationship between trust and firm performance. Specifically, product development provides partial mediating effect on the relationship between trust and firm performance.

\section{Discussion}

The result confirms that the process of open innovation involves network structures, trust, product development, and firm performance. Both trust and product development plays pivotal role on the observed SMEs through providing mediating effect on the relationship between network structure and firm performance. The framework shows that trust 
provides full mediating effect between network structure and product development, which determines the firm performance. There is no direct effect of network structure on both product development and firm performance.

Network structure is necessary for the firms to achieve their performance, but not sufficient. Dense network structure may become a source of competitive advantage that allows firms to achieve their great performance (Suli et al., 2013), however, result indicates there is dense network structure does not always provide positive impact on firm performance. Firms with spare network structure may still gain greater performance as firm with sparse network structure may focus on attractive partners who translate the available information into valuable resources (Milanov and Shepherd, 2013).

Product development is essential element of marketing capability, which can bring positive impact on firm performance (Morgan et al., 2009). In the context of open innovation, the firms require their network structure to product development with moderating effect of trust. Trust plays pivotal role on the process of open innovation through fully mediating the relationship between networks structure and product development as well as firm performance.

The concept of trust involves high reciprocity, mutual trust among the colleagues, as well as dealing with customers. This indicates that trust is also essential element of strategic organisation as well as customer relationship. Firms with wide range of actors and arm's length relationship might be activated for innovation project (Rusanen et al., 2014).

Networks without trust may bring a potential risk of innovation failure. With trust, the innovator partners believe that the firms would cover the risk and not leave them if something went wrong with the innovation. Hence, future study is encouraged to explore the risk of innovation failure that springs from open innovation.

Firm performance may depend on their offering products that exhibit network effect (Afuah, 2013). However, the framework seems to be too far as it tries to relate network structure to firm performance. Firm performance depends on host of other essential variables, such as financial strategy, marketing strategy, and government policy. Those essential variables should not be controlled. Hence, future research should consider those factors.

Last but not least, this study has some other limitations, which may bring possible bias information. First, the source of information comes from a single key informant, which is expected to represent a firm as unit analysis. Future research could examine similar characteristics with various stakeholders, including employees and research partners. Second, the results of this study represent a cross-section observation, which concern on one specific point in time. Future studies may involve longitudinal data observation.

\section{Conclusions}

This study complements the literatures on RBV through investigating firms that develop multiple types of dynamic capabilities in the field of alliances and product development. Hence, this study provides extended contribution through providing empirical evident that a success of product development requires capability to transform network structure as valuable resource into product development toward firm performance, which involves trust as main element of social capital. 
The study confirms that a network structure and trust provide value on product development. Hence, the expansion of network structures has no significant impact on product development as well as on firm performance, unless the firms have dynamic capability to building trust on the open innovation process. This confirms previous studies that neglecting trust and focuses only on size can lead to wrong strategies (Afuah, 2013).

As dynamic capabilities include strategic process like alliancing and product development (Eisenhardt and Martin, 2000), this study draws conclusion that trust is essential element of alliancing and product development. The result confirms that managing the open innovation requires various competences to deal with diverse stakeholders who get involved in open innovation process (Corvello et al., 2013).

\section{Acknowledgements}

The author would like to thank to the reviewers for their valuable comments.

\section{References}

Afuah, A. (2013) 'Are network effect really all about size? The role of structure and conduct', Strategic Management Journal, Vol. 34, No. 3, pp.257-273.

Alguezaui, S. and Fillieri, R. (2010) 'Investigating the role of social capital in innovation: sparse versus dense network', Journal of Knowledge Management, Vol. 14, No. 6, pp.891-909.

Barney, J. (1991) 'Firm resources and sustained competitive advantage', Journal of Management, Vol. 17, No. 1, pp.99-120.

Becker, J-M., Rai, A., Ringle, C. and Völckner, F. (2013) 'Discovering unobserved heterogeneity in structural equation models to avert validity threats', MIS Quarterly, Vol. 37, No. 3, pp.665-695.

Bidault, F. and Castello, A. (2010) 'Why too much trust is death to innovation', MIT Sloan Management Review, Vol. 51, No. 4, pp.33-38.

Bjørnskov, C. and Sønderskov, K. (2013) 'Is social capital good?', Social Indicator Research, Vol. 114, No. 3, pp.1225-1242.

Braguinsky, S. and Hounshell, D. (2016) 'History and nanoeconomics in strategy and industry revolution research: lesson from the Meiji-era Japanese cotton spinning industry', Strategic Management Journal, Vol. 37, No. 1, pp.45-65.

Broadbridge, A. (2010) 'Social capital, gender and careers: evidence from retail senior managers', Equality, Diversity and Inclusion: An International Journal, Vol. 29, No. 8, pp.815-834.

Bstieler, L. (2006) 'Trust formation in collaborative new product development', Product Innovation Management, Vol. 23, No. 1, pp.56-72.

Byrne, B. (2010) Structural Equation Modeling with AMOS, Taylor and Francis, New York

Casadesus-Masanell, R. and Zhu, F. (2013) 'Business model innovation and competitive imitation: the case of sponsor-based business model', Strategic Management Journal, Vol. 34, No. 9, pp.464-482.

Ceserani, J. (2014) 'Innovation and trust - the path to mastery', Industrial and Commercial Training, Vol. 46, No. 6, pp.302-306.

Chesbrough, H. (2003) Open Innovation: The New Imperative for Creating and Profiting from Technology, Harvard Business School Press, Boston.

Chetty, S. and Stangl, L. (2010) 'Internationalization an innovation in a network relationship context', European Journal of Marketing, Vol. 44, No. 11, pp.1725-1743. 
Clifton, N., Keast, R., Pickernell, D. and Senior, M. (2010) 'Network structure, knowledge governance, and firm performance: evidence from innovation networks and SMEs in the UK', Growth and Change, Vol. 41, No. 3, pp.337-373.

Clopton, A. (2011) 'Social capital and team performance', Team Performance Management, Vol. 17, Nos. 7/8, pp.369-381.

Corvello, V., Gitto, D., Carlsson, S. and Migliarese, P. (2013) 'Using information technology to manage diverse knowledge sources in open innovation processes', in Lundström, J. et al. (Eds.): Managing Open Innovation Technologies, pp.179-197, Springer, Heidelberg, Berlin.

Costa, L., Cool, K. and Dierickx, I. (2013) 'The competitive implication of deployment of unique resources', Strategic Management Journal, Vol. 34, No. 4, pp.445-463.

Cvtanovic, S., Despotovic, D. and Filipovic, M. (2015) 'The concept of social capital in economic theory', Ekonomika, Vol. 61, No. 1, pp.73-84.

Dovey, K. (2009) 'The role of trust in innovation', The Learning Organization, Vol. 16, No. 4, pp.311-325.

Duffy, M., Scott, K., Shaw, J., Tepper, B. and Aquino, K. (2012) 'A social context model of envy and social undermining', Academy of Management Journal, Vol. 55, No. 3, pp.643-666.

Dutta, S., Zbaracki, M. and Bergen, M. (2003) 'Pricing process as capability: a resource-based perspective', Strategic Management Journal, Vol. 24, No. 7, pp.615-630.

Eisenhardt, K. and Martin, J. (2000) 'Dynamic capabilities: what are they?', Strategic Management Journal, Vol. 21, Nos. 10/11, pp.1105-1121.

Eisenman, M. (2013) 'Understanding aesthetic innovation in the context of technological evolution', Academy of Management Review, Vol. 38, No. 3, pp.332-351.

Fadol, Y. and Sandhu, M. (2013) 'The role of trust on the performance of strategic alliances in a cross-cultural context', Benchmarking, Vol. 20, No. 1, pp.106-128.

Frazier, G., Maltz, E., Antia, K. and Rindfleisch, A. (2009) 'Distributor sharing of strategic information with suppliers', Journal of Marketing, Vol. 73, No. 4, pp.31-43.

Gausdal, A. and Hildrum, J. (2012) 'Facilitating trust building in networks: a study from the water technology industry', Systemic Practice and Action Research, Vol. 25, No. 1, pp.15-38.

Grund, T. (2012) 'Network structure and team performance: the case of English Premier League soccer team', Social Networks, Vol. 34, No. 4, pp.682-690.

Gu, F., Kim, N., Tse, D. and Wang, D. (2010) 'Managing distributors' changing motivation over the course of a joint sales program', Journal of Marketing, Vol. 74, No. 9, pp.32-47.

Hair, J., Sarstendt, M., Ringle, C. and Mena, J. (2012) 'An assessment of the use of partial least squares structural equation model in marketing research', Journal of Academic Marketing Science, Vol. 40, No. 3, pp.414-433.

Häuberer, J. (2010) Social Capital Theory: Toward a Methodological Foundation, Heidelberg, Springer Fachmedien Wiesbaden, Berlin.

Hearnshaw, E. and Wilson, M. (2013) 'A complex network approach to supply chain network theory', International Journal of Operation and Production Management, Vol. 33, No. 4, pp.442-469.

Huesch, M. (2013) 'Are there always synergies between productive resources and resources deployment capabilities?', Strategic Management Journal, Vol. 34, No. 11, pp.1288-1313.

Hunter, M. (2012) 'On some of misconceptions about entrepreneurship', Economics, Management and Financial Markets, Vol. 7, No. 2, pp.55-104.

Inauen, M. and Shenker-Wicki, A. (2011) 'The impact of outside-in open innovation on innovation performance', European Journal of Innovation Management, Vol. 14, No. 4, pp.496-520.

Jansen, R., Curseu, P., Vermeulen, P., Geurts, J. and Gibcus, P. (2011) 'Social capital as a decision aid in strategic decision-making in services organization', Management Decision, Vol. 49, No. 5, pp.734-747. 
Jonsson, S. and Lindbergh, J. (2013) 'The development of social capital and financing of entrepreneurial firms: from financial bootstrapping to bank funding', Entrepreneurship Theory and Practice, Vol. 37, No. 4, pp.661-686.

Kwon, S-W. and Adler, P. (2014) 'Social capital: maturation of a field of research', Academy of Management Review, Vol. 39, No. 4, pp.412-422.

Landwehr, J., Wentzel, D. and Herrman, A. (2013) 'Product design for the long run: consumer responses to typical and atypical design at different stage of exposure', Journal of Marketing, Vol. 77, No. 9, pp.92-107.

Langer, H. (2012) 'Job satisfaction and self-employment: autonomy or personality?', Small Business Economics, Vol. 38, No. 2, pp.165-177.

Lee, L.T. and Sukoco, B.M. (2007) 'The effects of entrepreneurial orientation and knowledge management capability on organizational effectiveness in Taiwan: the moderating role of social capital', International Journal of Management, Vol. 24, No. 3, pp.549-573.

Laeequddin, M., Sahay, B.S., Sahay, V. and Wahed, K.A. (2010) 'Measuring trust in supply chain partners' relationship', Measuring Business Excellence, Vol. 14, No. 3, pp.53-69.

Li, Q., Maggitti, P., Smith, K., Tesluk, P. and Katila, R. (2013) 'Top management attention to innovation: the role of search selection and intensify in new product introduction', Academy of Management Journal, Vol. 56, No. 3, pp.893-916.

Liozu, S. and Hinterhuber, A. (2013) 'Pricing orientation, pricing capabilities, and firm performance', Management Decision, Vol. 51, No. 3, pp.594-614.

Lockett, A., Currie, G., Finn, R., Martin, G. and Waring, J. (2014) 'The influence of social position on sensemaking about organizational change', Academy of Management Journal, Vol. 54, No. 4, pp.1102-1129.

Lumpkin, G., Cogliser, C. and Schneider, D. (2009) 'Understanding and measuring autonomy: an entrepreneurial orientation perspective', Entrepreneurship Theory and Practice, Vol. 33, No. 1, pp.47-69.

Ma, Z., Yang, Z. and Mourali, M. (2014) 'Consumer adoption of new products: independent versus interdependent self-perspective', Journal of Marketing, Vol. 78, No. 2, pp.101-117.

Marin, A., Mitchell, R. and Lee, J. (2015) 'The vulnerability and strength duality in ethnic business: a model of stakeholder salience and social capital', Journal of Business Ethics, Vol. 130, No. 2, pp.271-289.

Milanov, H. and Shepherd, D. (2013) 'The importance of the first relationship: the ongoing influence of initial network on future status', Strategic Management Journal, Vol. 34, No. 9, pp.727-750.

Moran, C., Diefendoff, J., Kim, T. and Liu, Z. (2012) 'A profile approach to self-determination theory motivation to work', Journal of Vocation Behavior, Vol. 81, No. 3, pp.354-363.

Morgan, N., Vorhies, D. and Mason, C. (2009) 'Market orientation, marketing capabilities, and firm performance', Strategic Management Journal, Vol. 30, No. 8, pp.909-920.

Murray, J., Gao, G. and Kotabe, M. (2011) 'Market orientation and performance of export ventures: the process through marketing capabilities and competitive advantage', Journal of Academic Marketing Science, Vol. 39, No. 2, pp.252-369.

Nätti, S., Hurmelinna-Laukkanen, P. and Johnston, W. (2014) 'Absorptive capacity and network orchestration in innovation communities - promoting service innovation', The Journal of Business and Industrial Marketing, Vol. 29, No. 2, pp.173-184.

Newman, M., Barabási, A. and Watts, D. (2006) The Structure and Dynamics of Networks, Princeton University Press, New Jersey.

Oldroyd, J. and Morris, S. (2012) 'Catching falling stars: a human resource response to social capital's detrimental effect of information overload on star employees', Academy of Management Review, Vol. 37, No. 3, pp.398-418. 
Para-Requena, G., Ruiz-Ortega, M. and Garcia-Villaverde, P. (2012) 'Towards pioneering through capabilities in dense and cohesive social networks', Journal of Business and Industrial Marketing, Vol. 27, No. 1, pp.41-56.

Parkman, I., Hollow, S. and Sebastian, H. (2012) 'Creative industries: aligning entrepreneurial orientation and innovation capacity', Journal of Research in Marketing and Entrepreneurship, Vol. 14, No. 1, pp.95-114.

Penrose, E. (1959) The Theory of the Growth of the Firm, Oxford University Press, Oxford.

Pitta, D. and Pitta, E. (2012) 'Transforming the nature and scope of new product development', Journal of Product and Brand Management, Vol. 21, No. 1, pp.35-46.

Pratono, A. and Mahmod, R. (2014) 'Social capital and firm performance: moderating effect of environmental turbulence', Asian Social Science, Vol. 10, No. 19, pp.59-68.

Putnam, R. (2000) Bowling Alone, Simon and Schuster Paperbacks, New York.

Rusanen, H., Halinen-Kaila, A. and Jaakkola, E. (2014) 'Accessing resources for service innovation - the critical role of network relationships', Journal of Service Management, Vol. 25, No. 1, pp.2-29.

Schaubroeck, J., Peng, A. and Hannah, S. (2013) 'Developing trust with peers and leaders: impacts on organizational identification and performance during entry', Academy of Management Journal, Vol. 56, No. 4, pp.1148-1168.

Schilke, O. (2014) 'On the contingent value of dynamic capabilities for competitive advantage: the nonlinear moderating effect of environmental dynamism', Strategic Management Journal, Vol. 35, No. 2, pp.179-203.

Spullberg, D. (2009) The Theory of the Firm: Microeconomics with Endogenous Entrepreneurs, Firm, Market and Organization, Cambridge University Press, Cambridge.

Suli, Z., Li, H. and Wu, X. (2013) 'Network resources and the innovation performance: evidence from Chinese manufacturing firms', Management Decision, Vol. 51, No. 6, pp.1207-1224.

Terpend, R. and Ashenbaum, B. (2012) 'The intersection of power, trust, and supplier network size: implication for supplier performance', Journal of Supply Chain Management, Vol. 48, No. 3, pp.52-77.

Trez, G. and Luce, F. (2012) 'Organizing structure and specializing marketing capabilities in SMEs', Marketing Intelligence \& Planning, Vol. 30, No. 2, pp.143-164.

Tubadji, A. (2014) 'Was Weber right? The cultural capital root of socio-economic growth examined in five European countries', International Journal of Manpower, Vol. 35, Nos. 1/2, pp.56-88.

West, J., Salter, A., Vanhaverbeke, W. and Chesbrough, H. (2014) 'Open innovation: the next decade', Research Policy, Vol. 43, No. 5, pp.805-811.

Xie, W. and White, S. (2006) 'From imitation to creation: the critical yet uncertain transition for Chinese firms', Journal of Technology Management, Vol. 1, No. 3, pp.229-242.

Zaheer, A. and Bell, G. (2005) 'Benefiting from network position: firm capabilities, structural holes, and performance', Strategic Management Journal, Vol. 26, No. 9, pp.809-825.

Zellweger, T. and Sieger, P. (2010) 'Entrepreneurial orientation in long-lived family firms', Small Business Economics, Vol. 38, No. 1, pp.67-84.

Zheng, S., Li, H. and Wu, X. (2013) 'Network resources and the innovation performance: evidence from Chinese manufacturing firms', Management Decision, Vol. 51, No. 6, pp.1207-1224. 


\section{Appendix 1}

Table A1 Outer weights

\begin{tabular}{|c|c|c|c|}
\hline Items & Measures & Original sample $(O)$ & $t$-value \\
\hline $\mathrm{FP} 1<\mathrm{FP}$ & $\begin{array}{l}\text { Sales growth performance during the last } \\
\text { three years. }\end{array}$ & 0.142696 & 12.533632 \\
\hline $\mathrm{FP} 2<\mathrm{FP}$ & Sales growth relative to direct competitors. & 0.177979 & 24.815925 \\
\hline $\mathrm{FP} 3<\mathrm{FP}$ & $\begin{array}{l}\text { Employment growth rate in the last three } \\
\text { years. }\end{array}$ & 0.073410 & 4.267513 \\
\hline $\mathrm{FP} 4<\mathrm{FP}$ & Gross profit in the last three years. & 0.161093 & 15.519732 \\
\hline FP5 $<$ FP & Return on asset (ROA) & 0.177008 & 19.404511 \\
\hline FP6 $<$ FP & Return on investment (ROI) & 0.182318 & 21.781631 \\
\hline FP7 $<$ FP & Return on sales (ROS) & 0.178554 & 20.443433 \\
\hline FP8 $<$ FP & Overall performance in the last three years. & 0.188056 & 23.491970 \\
\hline $\mathrm{NS} 1<\mathrm{NS}$ & $\begin{array}{l}\text { In our firm, all division recognise that we } \\
\text { need each other to accomplish our objectives. }\end{array}$ & 0.327908 & 22.302949 \\
\hline $\mathrm{NS} 2<\mathrm{NS}$ & $\begin{array}{l}\text { In our firm, sales people would be just as } \\
\text { effective without working with other } \\
\text { divisions (R). }\end{array}$ & 0.221592 & 17.005217 \\
\hline $\mathrm{NS} 3<\mathrm{NS}$ & $\begin{array}{l}\text { By working with universities or research } \\
\text { institutions, our product division gets access } \\
\text { to resources and product ideas. }\end{array}$ & 0.275111 & 19.336707 \\
\hline NS4 $<$ NS & Our firm knows our suppliers in persons. & 0.176970 & 6.828036 \\
\hline NS5 $<$ NS & $\begin{array}{l}\text { Our firm maintains close social relationship } \\
\text { with buyers. }\end{array}$ & 0.248822 & 12.293465 \\
\hline NS6 $<\mathrm{NS}$ & $\begin{array}{l}\text { The exchange of information among our } \\
\text { contacts in research institutions usually has a } \\
\text { similar content. }\end{array}$ & 0.310533 & 24.719638 \\
\hline $\mathrm{NS} 7<\mathrm{NS}$ & $\begin{array}{l}\text { The contacts with which we maintain } \\
\text { frequent relationships, in general, know each } \\
\text { other. }\end{array}$ & -0.038439 & 1.515115 \\
\hline $\mathrm{NS} 8<\mathrm{NS}$ & $\begin{array}{l}\text { The contacts from which we receive advices } \\
\text { or information for making important } \\
\text { decisions have strong relationship. }\end{array}$ & 0.149605 & 8.304810 \\
\hline $\mathrm{TR} 1<\mathrm{TR}$ & $\begin{array}{l}\text { Our colleagues always keep their promises to } \\
\text { us. }\end{array}$ & 0.079994 & 3.128072 \\
\hline $\mathrm{TR} 2<\mathrm{TR}$ & $\begin{array}{l}\text { Our firm' is characterised by high } \\
\text { reciprocity. }\end{array}$ & 0.155533 & 8.108801 \\
\hline $\mathrm{TR} 3<\mathrm{TR}$ & $\begin{array}{l}\text { Our firm is characterised by mutual trust } \\
\text { among the colleagues at multiple levels. }\end{array}$ & 0.234567 & 14.497098 \\
\hline $\mathrm{TR} 4<\mathrm{TR}$ & $\begin{array}{l}\text { Our staff shares organisation vision with each } \\
\text { other. }\end{array}$ & 0.258573 & 19.926193 \\
\hline $\mathrm{TR} 5<\mathrm{TR}$ & $\begin{array}{l}\text { There is a good understanding among our } \\
\text { firm's partners. }\end{array}$ & 0.248717 & 17.082041 \\
\hline
\end{tabular}


Table A1 Outer weights (continued)

\begin{tabular}{|c|c|c|c|}
\hline Items & Measures & Original sample $(O)$ & t-value \\
\hline TR6 $<$ TR & Our strategic alliance is about mutual respect. & 0.112273 & 21.957733 \\
\hline TR7 $<$ TR & $\begin{array}{l}\text { Our strategic alliance is characterised by } \\
\text { personal friendship. }\end{array}$ & 0.149783 & 31.645618 \\
\hline TR8 $<$ TR & $\begin{array}{l}\text { Our strategic alliance of our firm is } \\
\text { characterised by personal friendship among } \\
\text { the top managers. }\end{array}$ & 0.124427 & 19.176117 \\
\hline TR9 $<$ TR & $\begin{array}{l}\text { Our staffs are good at dealing with } \\
\text { customers. }\end{array}$ & 0.146315 & 26.649481 \\
\hline $\mathrm{PD} 1<\mathrm{PD}$ & $\begin{array}{l}\text { Our firm produces new products in open } \\
\text { ways. }\end{array}$ & 0.122404 & 16.066350 \\
\hline $\mathrm{PD} 2<\mathrm{PD}$ & $\begin{array}{l}\text { Our firm exploits R\&D investment with } \\
\text { various stakeholders. }\end{array}$ & 0.143837 & 30.140516 \\
\hline $\mathrm{PD} 3<\mathrm{PD}$ & $\begin{array}{l}\text { Our firm speedily develops and launches new } \\
\text { products. }\end{array}$ & 0.149054 & 31.734954 \\
\hline $\mathrm{PD} 4<\mathrm{PD}$ & $\begin{array}{l}\text { Our firm carries out test marketing of new } \\
\text { product/services. }\end{array}$ & 0.147887 & 34.202069 \\
\hline PD5 < PD & $\begin{array}{l}\text { Our firm makes sure that links with } \\
\text { participant are responsive to customer needs. }\end{array}$ & 0.134763 & 22.996388 \\
\hline
\end{tabular}

\section{Appendix 2}

Table A2 Loading factors

\begin{tabular}{lcccc}
\hline & FP & NS & PD & Trust \\
\hline FP01 & 20.758672 & & \\
FP02 & 46.307628 & & \\
FP03 & 5.863519 & & \\
FP04 & 23.102637 & & \\
FP05 & 28.910668 & & \\
FP06 & 37.274171 & & \\
FP07 & 31.918204 & & \\
FP08 & 36.976329 & & 53.326208 \\
PD1 & & & 31.725935 \\
PD2 & & & 34.000559 \\
PD3 & & & 19.337530 \\
PD4 & & & 28.004466 \\
PD5 & & 5.175457 & \\
NS1 & & 1.085073 & \\
NS2 & & 6.480024 & \\
NS3 & & 5.466856 & \\
NS4 & & & \\
\hline
\end{tabular}


Table A2 Loading factors (continued)

\begin{tabular}{lccc}
\hline & FP & NS & PD \\
\hline NS5 & 12.031558 & Trust \\
NS6 & 19.182521 & \\
NS7 & 20.822319 & \\
NS8 & 28.624781 & \\
TR1 & & \\
TR2 & & 25.572104 \\
TR3 & & 41.874271 \\
TR4 & & 23.619923 \\
TR5 & & 31.325931 \\
TR6 & & 24.858217 \\
TR7 & & 42.447003 \\
TR8 & & 52.046651 \\
TR9 & & 62.735758 \\
\hline
\end{tabular}


LOG IN

For Authors, Editors, Board Members

Username

Remember me

\section{Linking academia, business and industry through research}

\section{Home \\ For Authors \\ For Librarians \\ Orders \\ Inderscience Online \\ Home > International Journal of Business Innov ation and Research \\ International Journal of Business Innovation and Research}

\section{News}

Article search Go

2. This journal also publishes Open Access articles

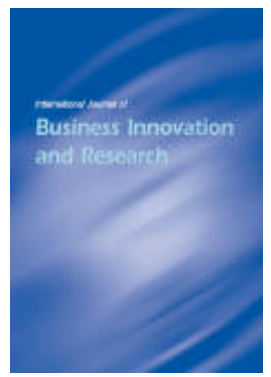

Editor in Chief: Prof. Angappa Gunasekaran

ISSN online: $1751-0260$

ISSN print: 1751-0252

12 issues per year

Subscription price

Calls for papers

One of the largest unrealised opportunities in organisations is fully leveraging ideas and knowledge to transform business processes into continuing innovation. Global markets and operations force companies to rethink business innovation and research activities and in turn their overall competitiveness. Business innovation and research contribute significantly to improvement in enterprise productivity and quality, integral components of business strategy and success. IJBIR covers developments in the theory and applications of business and entrepreneurship innovation strategies, methods and tools to enhance competitiveness.

\section{About this journal}

\section{Editorial Board}

\section{Submitting articles}

\section{Topics covered include}

- Business research methods

- Innovation in finance/accounting

- International business/finance

- Strategy innovation, strategic alliances, BPR

- Business research for decision making

- Innovation/research in marketing, SMEs

- Buyer/consumer behaviour, CSR

- Global supply chain/networks, outsourcing, export/import, retailing

- Organisational competitiveness/learning/leadership

- Service industries, healthcare, new product/process innovation

- Empirical analysis, case studies, performance measures

- Benchmarking/best practices in innovation activities

- Role of IT/IS, e-business, technological innovation

- Knowledge management, technology transfer

- Business law, ethics, environmental standards

More on this journal...
Sign up for new issue alerts

Subscribe/buy articles/issues

$\checkmark$ View sample issue

Latest issue contents as RSS feed

Forthcoming articles

D Journal information in easy print format (PDF)

Publishing with Inderscience: ethical guidelines (PDF)

$\checkmark$ View all calls for papers

$\checkmark$ Recommend to a librarian

$\checkmark$ Feedback to Editor

Find related journals

Find articles and other searches

\section{Keep up-to-date}

Our Blog

Follow us on Twitter

fi Visit us on Facebook

87 Join us on Google+

Our Newsletter (subscribe for free)

RSS feed

New issue alerts

SHARE 
Vol. 17

ç 'วl. 16

15

Vol. 14

Vol. 13

Vol. 12

More volumes...

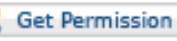

More on permissions
- Scopus (Elsevier)

- Academic OneFile (Gale)

- Asian Digital Library

- cnpLINKer (CNPIEC)

- Google Scholar

More indexes...

\section{IJBIR is listed in:}

- Chartered Association of Business Schools (CABS) Academic Journal Guide

- Australian Business Deans Council Journal Rankings List

More journal lists/directories...

\section{Journal news}

\section{Repurposing consumers}

People often find weird and wonderful alternative uses for the products they buy. For example, coal drinks have been used as household cleaner, construction toys such as Lego and Meccano are often used to ad lib rigs for a variety of purposes such as to support cameras, and of course many people "hack" their game consoles or other devices to do computational and communications jobs for which the device was not originally designed. And for many years, people have ripped old clothing into rags for a wide range of cleaning applications [...] More details.. Enterprises Ltd. 
LOG IN

For Authors, Editors, Board Members

Username

Remember me

\section{Linking academia, business and industry through research}

\section{Home \\ For Authors \\ For Librarians \\ Orders \\ Inderscience Online \\ Home > International Journal of Business Innov ation and Research \\ International Journal of Business Innovation and Research}

D. This journal also publishes Open Access articles

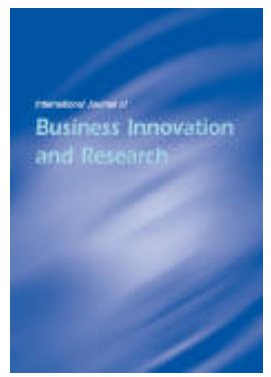

Editor in Chief: Prof. Angappa Gunasekaran

ISSN online: $1751-0260$

ISSN print: 1751-0252

12 issues per year

Subscription price

One of the largest unrealised opportunities in organis ations is fully leveraging ideas and knowledge to transform business processes into continuing innovation. Global markets and operations force companies to rethink business innovation and research activities and in turn their overall competitiveness. Business innovation and research contribute significantly to improvement in enterprise productivity and quality, integral components of business strategy and success. IJBIR covers developments in the theory and applications of business and entrepreneurship innovation strategies, methods and tools to enhance competitiveness.

\begin{tabular}{|l|l|}
\hline About this journal & Editorial Board \\
\hline
\end{tabular}

\section{Editor in Chief}

- Gunasekaran, Angappa, California State University, Bakersfield, USA

(an.gunasekaran@gmail.com)

\section{Editorial Board Members}

Abrahamson, Eric, Columbia University, USA

Amoako-Adu, Ben, Wilfrid Laurier University, Canada

Bagley, Constance E., Yale University, USA

Balachandran, Bala K. R., New York University, USA

Brannen, Mary Yoko, San Jose State University, USA

Brem, Alexander, Friedrich-Alexander-Universität Erlangen-Nürnberg (FAU), Germany

Bruce, Margaret, Manchester Business School, UK

Burke, Andrew, Cranfield University, UK

Carmon, Ziv, INSEAD, Singapore

Carter, Sara, University of Stirling, UK

Chandran, Rajan, Temple University, USA

Chandrasekar, Venkat, Indian School of Business, India

Chataway, Joanna, RAND Europe, UK

Chattopadhyay, Amitava, INSEAD, France

Clarke, Steve, The University of Hull, UK
Sign up for new issue alerts

Subscribe/buy articles/issues

$\checkmark$ View sample issue

Latest issue contents as RSS feed

Forthcoming articles

$\checkmark$ Journal information in easy print format (PDF)

Publishing with Inderscience: ethical guidelines (PDF)

$\checkmark$ View all calls for papers

- Recommend to a librarian

$\checkmark$ Feedback to Editor

Find related journals

Find articles and other searches

\section{Keep up-to-date}

Our Blog

Follow us on Twitter

If Visit us on Facebook

8. Join us on Google+

Our Newsletter (subscribe for free)

RSS feed

New issue alerts

SHARE 
Clayton, Garry, Eastern Institute of Technology, New Zealand

Enz, Cathy, Cornell University, USA

Erekson, O. Homer, Texas Christian University, USA

Francis, G. James, Colorado State University, USA

Ghobadian, Abby, Henley Management College, UK

Hammoudeh, Shawkat, Drexel University, USA

Holian, Rosalie, RMIT University, Australia

Hussain, Md. Mostaque, Sultan Qaboos University, Oman

Jain, Subhash C., University of Connecticut, USA

Jakobsen, Arnt Lykke, Copenhagen Business School, Denmark

Kim, Ken, The University of Toledo, USA

Klein, Linda, University of Connecticut, USA

Kwon, Ik-Whan G., St. Louis University, USA

Kyrö, Paula, Helsinki School of Economics, Finland

Lank, David M., McGill University, Canada

Lindsay, Noel J., University of South Australia, Australia

Maclean, Mairi, University of the West of England, UK

Martikainen, Minna, Lappeenranta University of Technology, Finland

Massey, Claire, Massey University, New Zealand

Mathe, Hervé, ESSEC, France

Mazumdar, Tridib, Syracuse University, USA

McDonough III, Edward F., Northeastern University, USA

Mehrotra, Anuj, University of Miami, USA

Mitra, Jay, University of Essex, UK

Mouritsen, Jan, Copenhagen Business School, Denmark

Moutinho, Luiz, University of Glasgow, UK

Quigley, John M, University of California, Berkeley, USA

Söderman, Sten, Stockholm University, Sweden

Saee, John, Swinburne University of Technology, Australia

Sankaran, Jay, University of Auckland, New Zealand

Smith, Alan D., Robert Morris University, USA

Sparrow, John, Birmingham City University, UK

Stern, Scott, Northwestern University, USA

Tann, Jennifer, University of Birmingham, UK

Trehan, Kiran, University of Central England, UK

Tsui, Eric, The Hong Kong Polytechnic University, Hong Kong SAR, China

Waddell, Dianne, Deakin University, Australia

White, D. Steven, University of Massachusetts-Dartmouth, USA

Wilke, Ricky, Copenhagen Business School, Denmark

Williams, Jeffrey R., Carnegie Mellon University, USA

Williams, Robin, University of Edinburgh, UK

Wright, Paul K., University of California at Berkeley, USA

Xu, Di, Xiamen University, China

\section{Journal news}

\section{Repurposing consumers}

People often find weird and wonderful alternative uses for the products they buy. For example, coal drinks have been used as household cleaner, construction toys such as Lego and Meccano are often used to ad lib rigs for a variety of purposes such as to support cameras, and of course many people "hack" their game consoles or other devices to do computational and communications jobs for which the device was not originally designed. And for many years, people have ripped old clothing into rags for a wide range of cleaning applications [...]

More details... 
LOG IN

For Authors, Editors, Board Members

\section{Username}

Remember me

\section{NDERSCIENCE P U B L I S H E R S}

\section{Linking academia, business and industry through research}

\section{For Authors \\ Orders \\ Inderscience Online \\ Home > International Journal of Business Innov ation and Research > 2018 Vol. 15 No. 1 \\ International Journal of Business Innovation and Research}

News

Article search

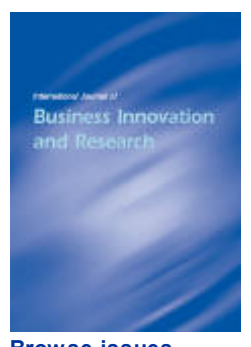

Browse issues

Vol. 17

Vol. 16

Vol. 15

Vol. 14

Vol. 13

Vol. 12

Vol. 11

Vol. 10

Vol. 9

Vol. 8

Vol. 7

Vol. 6

Vol. 5

Vol. 4

Vol. 3

Vol. 2

Vol. 1
2018 Vol. 15 No. 1

\section{Pages Title and authors}

1-13 Multi-dimensional nature of innovation at Amazon Jesse Arnett; Brion Goldfinch; Ravi Chinta DOI: 10.1504/IJBIR.2018.088461

14-33 Performance outcomes of interaction, balance, and alignment between exploration and exploitation in the technological innovation domain

David Cembrero; Josune Sáenz

DOI: 10.1504/IJBIR.2018.088464

34-43 Co-existence of social media and work productivity? Jehangir Bharucha

DOI: $10.1504 /$ IJBIR.2018.088465

44-61 Network structure and open innovation: the role of trust in product development

Aluisius Hery Pratono

DOI: $10.1504 / I J B I R .2018 .088467$

62-78 Predicting online buying behaviour - a comparative study using three classifying methods

Sanjeev Prashar; T. Sai Vijay; Chandan Parsad

DOI: 10.1504/IJBIR.2018.088468

79-98 What drives SME explorative-exploitative alliance formation: an integrated perspective

Ch.V.V.S.N.V. Prasad; Rohit Prabhudesai

DOI: 10.1504/IJBIR.2018.088471

99- Hesitation to adoption in the e-grocery retailing in an emerging

118 market

Bikramjit Rishi; H. Pradeep; Manaswini Vishwanathan

DOI: 10.1504/IJBIR.2018.088476

119- Influence of transformational-servant leadership styles and

135 justice perceptions on employee burnout: a moderated mediation model

S. Divya; L. Suganthi

DOI: 10.1504/IJBIR.2018.088475
Dign up for new issue alerts

- Subscribe/buy articles/issues

View sample issue

L Latest issue contents as RSS feed

Forthcoming articles

D Journal information in easy print format (PDF)

Publishing with Inderscience: ethical guidelines (pdf)

$\checkmark$ View all calls for papers

$\checkmark$ Recommend to a librarian

$\checkmark$ Feedback to Editor

Find related journals

Find articles and other searches

\section{Keep up-to-date}

Our Blog

Follow us on Twitter

f Visit us on Facebook

27 Join us on Google+

Our Newsletter (subscribe for free)

A RSS feed

L. New issue alerts

SHARE 